\title{
Anatomopathological study of cardiomyopathy induced by doxorubicin in rats ${ }^{1}$
}

\author{
Estudo anatomopatológico da miocardiopatia induzida pela doxorrubicina em ratos
}

\begin{abstract}
José Carlos Dorsa Vieira Pontes ${ }^{\mathrm{I}}$, Jandir Ferreira Gomes Júnior ${ }^{\mathrm{II}}$, Guilherme Viotto Rodrigues da Silva ${ }^{\mathrm{III}}$, Ricardo Adala Benfatti", Amaury Edgardo Mont'Serrat Ávila Souza Dias ${ }^{\mathrm{IV}}$, João Jackson Duarte ${ }^{\mathrm{II}}$, Neimar Gardenal ${ }^{\mathrm{II}}$, Maçanori Odashirov ${ }^{\mathrm{V}}$ Carlos Henrique Marques dos Santos ${ }^{\mathrm{VI}}$
\end{abstract}

${ }^{\text {I }} \mathrm{PhD}$, Associate Professor, Surgery Department, UFMS, Mato Grosso do Sul, Brazil.

${ }^{\text {II }}$ Master, Assistant Professor, Surgery Department, UFMS, Mato Grosso do Sul, Brazil.

III Garduate Student, Medical School, UFMS, Mato Grosso do Sul, Brazil.

Iv Specialist, Fellow Master Degree, Assistant Professor, Surgery Department, UFMS, Mato Grosso do Sul, Brazil.

${ }^{v}$ Associate Professor, Surgery Department, UFMS, Mato Grosso do Sul, Brazil.

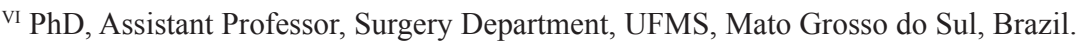

\begin{abstract}
Purpose: The development of an experimental model of myocardiopathy induced by Doxorubicin in rats. Methods: 16 wistar male rats were randomized in two groups: Group I (placebo) and Group II (Doxorubicin $-5 \mathrm{mg} / \mathrm{kg}$ ). After six months, the animals were subjected to cardiotomy and their hearts were weighted and submitted to transversal cuts, from which fragments for a macro and micro study were obtained. These fragments were studied considering their external and internal diameters and the thickness of the left ventricle (LV). The histological pieces were analyzed for the presence of fibrosis, cytoplasmic vacuolization, necrosis and size of nucleus variation. Data obtained was submitted to statistical analysis with Student's t test. Results: The hearts of the animals in Group II increased 41\% in relation to their weight; $33 \%$ in the internal diameter and 14\% in the external diameter of the LV cavity; and $24 \%$ in the thickness of the wall. Fibrosis of the myocardial tissue was observed in $75 \%$ of the animals of Group II; all the animals presented miocyte cytoplasmatic vacuolization; myocardial necrosis was present in $75 \%$ of the animals; and $87 / \%$ presented variation in the size of myocite nuclei. The presence of polymorphonuclear cells was also observed. Conclusion: Doxorubicin was effective in the promotion of macro and microscopic alterations in the cardiac tissue of rats, possibly constituting a model for the experimental study of myocardiopathy.
\end{abstract}

Key words: Cardiomyopathies. Doxorubicin. Rats.

\section{RESUMO}

Objetivo: Desenvolver um modelo experimental de miocardiopatia induzida por doxorrubicina em ratos. Métodos: 16 ratos Wistar machos foram randomizados em 2 grupos: Grupo I (placebo) e Grupo II (doxorrubicina 5mg/kg). Após 6 meses, os animais foram submetidos a cardiotomia e seus corações foram pesados e submetidos a cortes transversais. Estes fragmentos foram estudados considerando seus diâmetros externos e internos e a espessura do ventrículo esquerdo. As peças histológicas foram analisadas quanto à presença de fibrose, vacuolização citoplasmática, necrose e variação do tamanho do núcleo. Os resultados foram submetidos a análise estatística pelo teste t de Student. Resultados: Os corações dos animais do grupo II aumentaram 41\% em relação ao peso; 33\% no diâmetro interno e 14\% no diâmetro externo; e 24\% na espessura da parede do VE. Fibrose do tecido miocárdico foi observada em $75 \%$ dos animais do grupo II; todos os animais apresentaram vacuolização citoplasmática dos miócitos; Houve necrose miocárdica em 75\% dos animais e 87\% apresentaram variação no tamanho do núcleo. A presença de células polimorfonucleares também foi observada. Conclusão: A doxorrubicina foi efetiva na promoção de alterações macro e microscópicas no tecido cardíaco de ratos, possivelmente constituindo-se num modelo experimental para estudo da miocardiopatia.

Descritores: Cardiomiopatias. Doxorrubicina. Ratos.

${ }^{1}$ Research performed at Laboratory of Researches, Federal University of Mato Grosso do Sul (UFMS), Brazil. 


\section{Introduction}

Cardiovascular diseases are presently considered an important problem in public health, causing a high rate of mortality in the general population. Among these diseases, heart failure, defined as the heart's incapacity to adequately pump blood to meet the necessities of tissue metabolism or when it does pump blood at an anomalously elevated diastolic ventricular volume ${ }^{1}$.

Heart failure may have many etiologies. It may be due to cardiac muscle abnormalities such as myocardiopathy or cardiomyopathy (primary or idiopathic - no definite etiology) or specific of the myocardium. Miocardiopathy presents three distinct clinicopathological functional forms: dilated myocardiopathy, hypertrophic myocardiopathy and restrictive myocardiopathy. Dilated myocardiopathy is the most common form of the disease $(90 \%)$, while the restrictive form is less prevalent. The specific diseases of the cardiac muscle, in other words, those which present and known cause or that are associated to other systems' disorders, may cause any of the three functional patterns. This kind of myocardiopathy probably results from the final result of a myocardial lesion caused by many toxic, metabolic and infectious agents, neuromuscular diseases, storage disorders or other deposits, infiltrative or immunological disease ${ }^{2}$.

Many pharmacological agents (toxic agents) may acutely lesion the myocardium either causing myocarditis or a chronic lesion like that caused by dilated idiopathic myocardiopathy. Among these agents, we point out Doxorubicin².

Doxorubicin chloridrate (Adriamicin, Adriblastine) is one of the most effective anti-neoplastic agents in the treatment of a great variety of malignant tumors, including lymphoma, leukemia and solid tumors ${ }^{1,2}$. Doxorubicin is an anthraciclyne anti-cancer antibiotic that has cytotoxic action. Its main cytotoxic action is the inhibition of type II topoisomerase that induces DNA fragmentation, and eventually, cellular death. These agents also suffer the reduction of one and two electrons, generating intracellular free radicals, especially hydroxyl radicals that are highly cytotoxic ${ }^{3}$. Doxorubicin is intravenously administered and is quickly captured by many kinds of tissues. Extra-vascular infusion may cause local necrosis. It is mainly eliminated by bile.

Among Duxorubicin adverse side-effects, such as nausea, vomit, myelosuppression, and hair loss, is cardiotoxicity which limits its potential therapeutic use ${ }^{3}$. Cardotoxicity is dose dependent, causing irreversible damage to the myocardium, leading to the development of myocadiopathy and ensuing heart failure ${ }^{4}$. This type of cardiopathy develops itself when high doses are administered $\left(>550 \mathrm{mg} / \mathrm{m}^{2}\right)$. Approximately $7 \%$ of the patients to whom $550 \mathrm{mg} / \mathrm{kg}$ doxorubicin are administered for anticancer treatment will develop dilated myocardiopathy. This percentage increases when higher doses are administered ${ }^{5}$.

Symptoms occur earlier when the individual is already a cadiopathic patient. Doxorubicin acute toxicity occurs during or immediately following its administration and includes the following symptoms: tachycardia, hypotension, ST segment depression, T-waves electrocardiographic alterations. These are not worrisome symptoms since they disappear when the drug is suspended. The chronic effect, therefore, is irreversible myocardiopathy that may develop heart failure, after months or years of the beginning of the treatment, with the presentation of symptoms of congestive heart failure ${ }^{5}$

It has been proved that the development of good models of experimental studies is necessary to understand cardiomyopathies and heart failure better, due to their importance and prevalence in the general population. Singal et al. ${ }^{6}$ demonstrated the use of Doxorubicin in the induction of myocardiopathy. Myocardiopathy comparative studies demonstrated that the rat is the animal that is the most similar animal to a human being?

Taking into consideration what was discussed above, this work aims at the elaboration of an experimental study in rats, in order to evaluate the macro and micro antomopathological alterations of miocardiopathy induced by Doxorubicin.

\section{Methods}

The ethical principles of animal testing were followed, which have been established by the Brazilian School of Animal Testing (Colégio Brasileiro de Experimentação Animal - (COBEA). The research received approval from Ethic Committee of Federal University of Mato Grosso do Sul. Sixteen male, adult Wistar rats (Rattus norvegicus albinus) were studied. They came originally from the Animal Room of the Federal University of Mato Grosso do Sul with average weight $312 \mathrm{~g}$. The animals were randomized into two groups of eight rats: Group I - animals treated with placebo; group II animals treated with Doxoribicin.

The animals were anesthetized orally with sulfuric ether in a closed bell-jar. The caudal vein was submitted to cauterization with no 27 scalpel. Group II animals were administered 60U doxorubicin (unique dose), equivalent to $5 \mathrm{mg} / \mathrm{kg}$. Animals in Group I were administered the same volume of $0,9 \%$ physiological serum. During six months, the animals were kept in cages, being fed adequate food and water ad libitum.

After this period, cardiotomy was performed. The animals were anesthetized with the inhalation of sulfuric ether in closed bell-jars. Ample thoracotomy was performed with the resection of the costal cartilage for the exposition of the heart. Transversal cuts were made from $2 \mathrm{~cm}$ of the cardiac basis, obtaining fragments for the macroscopic study and for the microscopic study, afterwards. The heart of each animal was weighted in a AND HR-202 precision scale, soon after resection and adequately identified. The animals' hearts were studied as to the internal and external diameter of the left ventricle.

Hematoxylin-Eosin staining and Masson Trichromic were used. The histological pieces were evaluated for the presence of fibrosis, cytoplasmatic vacuolization, necrosis and size of nucleus variation.

Student's t Test was used at a 0.05 significance level.

\section{Results}

Macroscopic analysis

\section{$\underline{\text { Heart weight }}$}

An average $41 \%$ increase in Group II animal heart weight was observed compared to Group II animal heart weight (Table 1). 
TABLE 1 - Heart's weight (g) of each rat in Groups I and II

\begin{tabular}{ccc}
\hline & GRUPO I & GRUPO II \\
\hline \hline R1 & 1,272 & 1,8083 \\
R2 & 1,0019 & 2,1879 \\
R3 & 1,0336 & 1,5022 \\
R4 & 1,1517 & 1,1885 \\
R5 & 1,0421 & 1,2563 \\
R6 & 1,1345 & 1,3598 \\
R7 & 1,1218 & 1,597 \\
R8 & 1,0876 & 1,6241 \\
\hline Mean & 1,10565 & 1,5655125 \\
SD & 0,85528391 & 0,323995774 \\
p & 0,002348715 & \\
\hline
\end{tabular}

Internal diameter of the left ventricle cavity

A 33\% average increase in the internal diameter of the left ventricle cavity was observed in the hearts of Group II rats when compared to those of Group I (Table 2).

TABLE 2 - Internal diameter ( $\mathrm{mm}$ ) of the left ventricle cavity of each rat in Groups I and II

\begin{tabular}{ccc}
\hline & GRUPO I & GRUPO II \\
\hline R1 & 1,8 & 2,4 \\
R2 & 1,8 & 2,4 \\
R3 & 2,4 & 3 \\
R4 & 1,8 & 2,4 \\
R5 & 1,8 & 2,4 \\
R6 & 1,8 & 3,6 \\
R7 & 1,8 & 1,8 \\
R8 & 3 & 3,6 \\
Mean & 2,025 & 2,7 \\
SD & 0,446414285 & 0,641426981 \\
p & 0,015135988 & \\
\hline
\end{tabular}




\section{External diameter of the left ventricle cavity}

An average $14 \%$ increase in the external diameter of the left ventricle cavity was observed in Group II rats when compared to those of Group I (Table 3).

TABLE 3 - External diameter (mm) of the left ventricle cavity of each rat in Groups I and II

\begin{tabular}{ccc}
\hline & GRUPO I & GRUPO II \\
\hline \hline R1 & 9,6 & 13,2 \\
R2 & 8,4 & 13,2 \\
R3 & 10,8 & 11,4 \\
R4 & 10,2 & 10,8 \\
R5 & 10,8 & 11,4 \\
R6 & 10,2 & 10,8 \\
R7 & 10,2 & 10,8 \\
R8 & 11,4 & 12 \\
\hline Mean & 10,2 & 11,7 \\
SD & 0,907114735 & 1,014185106 \\
p & 0,003825851 & \\
\hline
\end{tabular}

\section{Thickness of left ventricle wall}

An average $24 \%$ increase on the thickness of the left ventricle wall was observed in the hearts of Group II rats when compared to those of Group I (Table 4).

TABLE 4 - Thickness (mm) of the left ventricle wall of each rat in Groups I and II

\begin{tabular}{ccc}
\hline & GRUPO I & GRUPO II \\
\hline \hline R1 & 2,4 & 3,6 \\
R2 & 2,4 & 3,6 \\
R3 & 3 & 3,6 \\
R4 & 3 & 3,6 \\
R5 & 3 & 3 \\
R6 & 2,4 & 3 \\
R7 & 3 & 3,6 \\
R8 & 2,4 & 3 \\
\hline Mean & 2,7 & 3,375 \\
SD & 0,32071349 & 0,310529502 \\
p & 0,000384541 & \\
\hline
\end{tabular}


Macroscopic analysis

\section{Fibrosis}

$75 \%$ of Group II rats presented myocadial fibrosis (Figure 1).

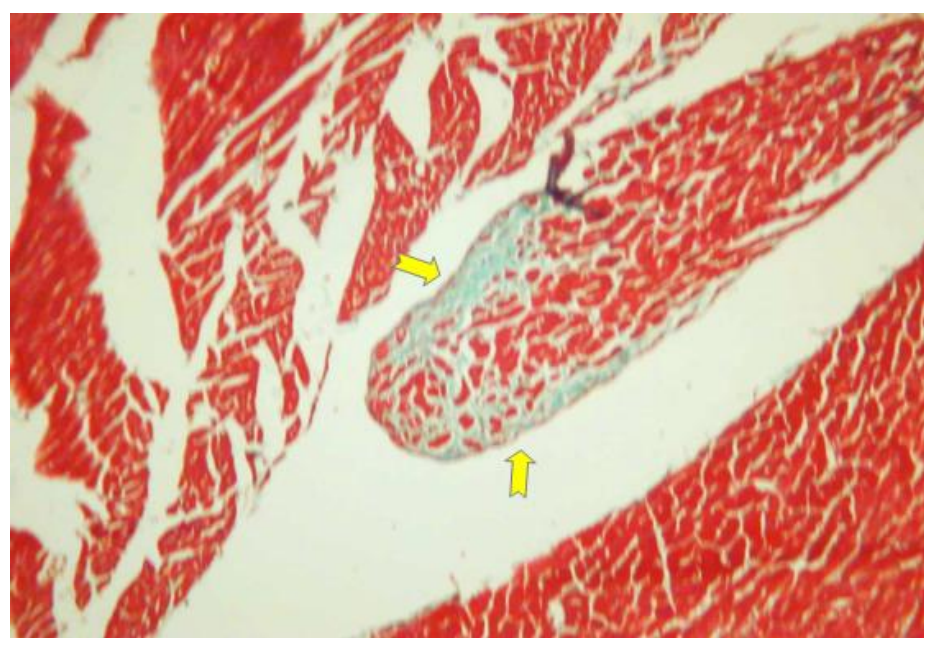

FIGURE 1 - Microscopic aspect of the myocardial tissue, showing the presence of fibrosis in the hearts of rats treated with Doxorubicin. Collagen fibers are stained blue. Masson's Trichome Staining. 100x amplified

\section{Cytoplasmatic vacuolization}

Myocite cytoplas-matic vacuolization was observed in $100 \%$ of Group II rats (Figure 2).

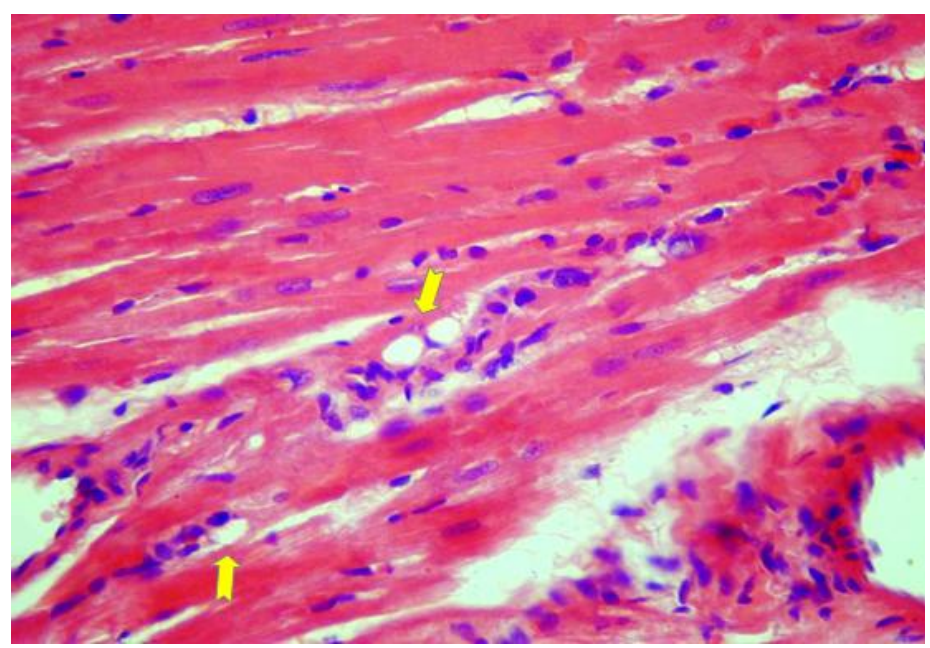

FIGURE 2 - Microscopic aspect of the myocardial tissue, showing the presence of cytoplasmatic myocite vacuolization in the animals treated with Doxorubicin. Hematoxylin - Eosin staining

\section{Necrosis}

$75 \%$ of Group II rats presented myocardial necrosis (Figure 3).

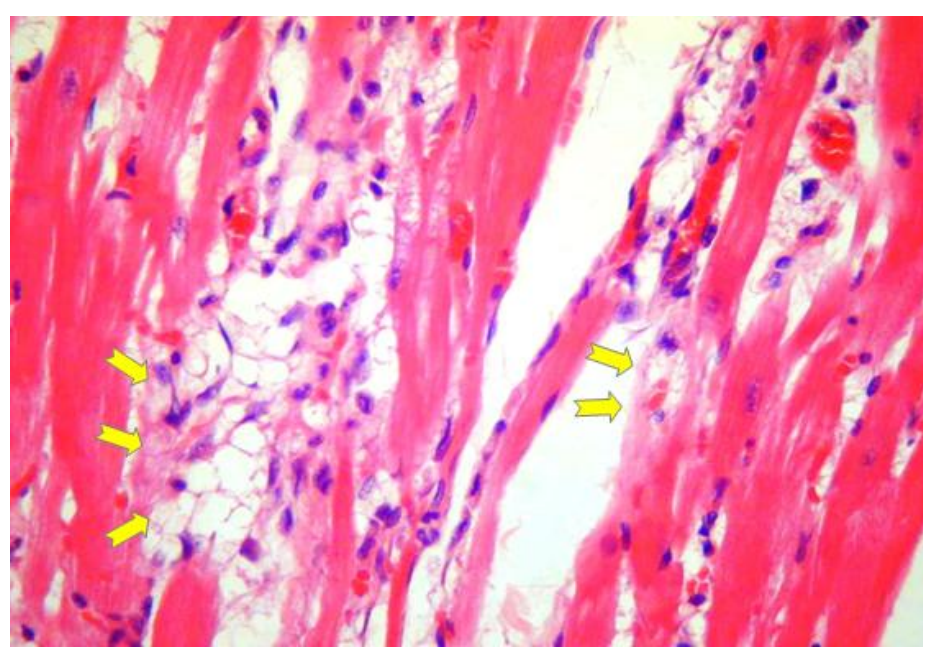

FIGURE 3 - Microscopic aspect of the myocardial tissue showing the presence of necrosis in animals' hearts treated with doxorubicin

\section{Variation in nucleus size}

$87 \%$ of Group II rats presented a variation in the size of the myocite nucleus (Figure 4).

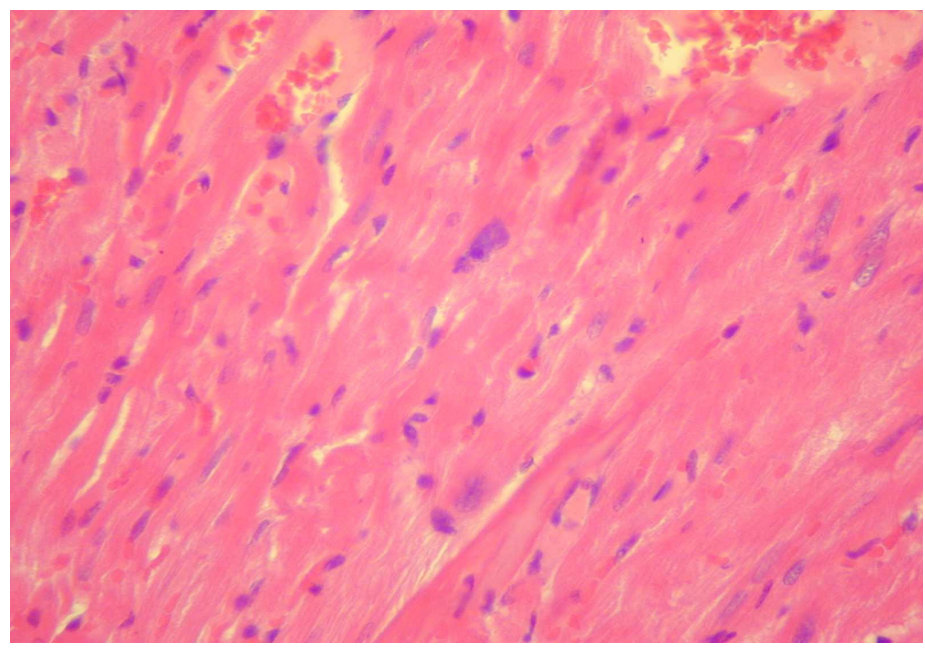

FIGURE 4 - Microscopic aspect of myocardial tissue showing size variation in myocite nuclei of rats treated with Doxuribicin 


\section{Other findings}

The presence of polimorphonuclear cells was also found in Group II animals (Figure 5).

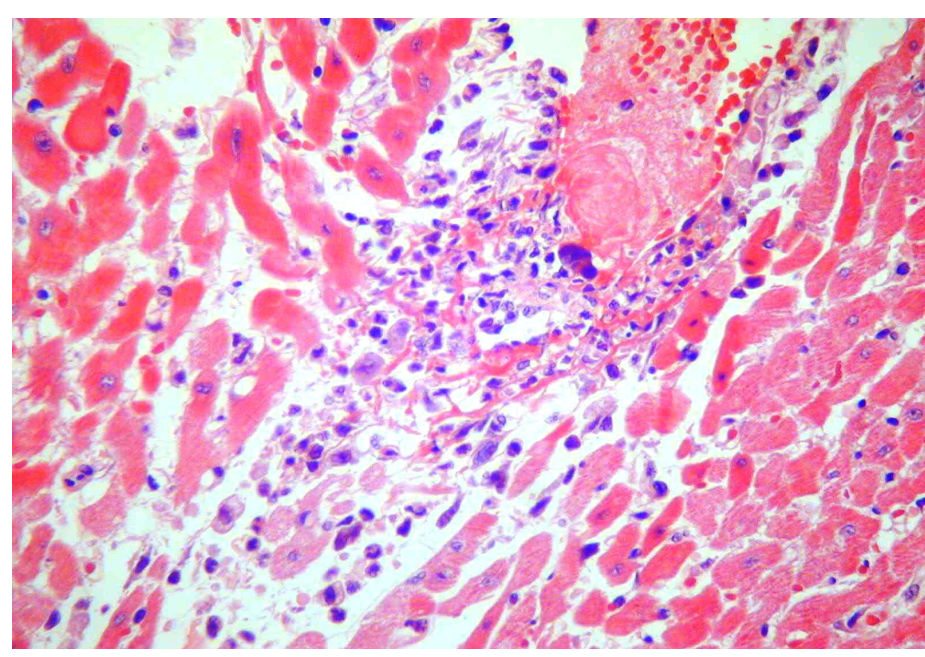

FIGURE 5 - Microscopic aspect of myocardial tissue showing the presence of polymorphonuclear infiltrate in the hearts of rats treated with Doxorubicin. Sub-endocardial necrosis was also observed. Hematoxylin Eosin staining. 440x amplified

\section{Discussion}

The literature on the subject registers that idiophatic myocardiopathy generally presents the dilation of all compartments, with determined thickening of the ventricular wall. Studies on histological cuts show the presence of fibrous myocardial scars in plaques (the major part of them are subendocardial). The histological alterations that occur in the process of dilated myocardiopathy show that the size of individualized muscular cells varies; most of them are hypertrophied, and some others are elongated. Interstitial endomyocardial fibrosis of various degrees is usually present and small scars frequently substitute isolate cells or group of cells, in other words, substitution fibrosis. Vacuolization is also present as well as muscular edema, fat alteration, lise of the individual cells and, sometimes, focal necrosis.

Many authors describe that Doxorubicin induced myocardiopathy may be established reproductively in rats $^{8,9}$. Studies with rats showed histological alterations similar to those that occur in humans: degeneration and loss of myocites, myocite compensatory hypertrophy of the rest of the myocites and interstitial fibrosis. The literature also reports the presence of cytoplasmatic vacuolization ${ }^{2}$. Majno et al. ${ }^{9}$ have observed fragmented and pycnotic nuclei, suggesting the possibility of apoptotic death ${ }^{9}$.

This study confirms the presence of such alterations in Doxorubicin induced myocardiopathy. In this investigation, a significant statistical increase in the rats' heart weight, in the thickness of the wall and in the internal and external diameter of the left ventricle was observed in rats treated with Doxorubicin, when compared with the control group. Microscopic analysis registered the presence of cytoplasmatic vacuolization in all studied pieces. Variation in nucleus size was observed in almost all samples. Interstitial fibrosis and necrosis was present in $75 \%$ of the animals' hearts.
The presence of polymorphonuclear cells was also registered.

The precise molecular mechanism of Doxorubicin induced myocardiopathy is still unknown. Many mechanisms have been proposed to explain the pathogenicity of this drug's cardiotoxicity. Some authors report an increase in the production of free radicals (FR) and a decrease in antioxidant enzymes activity. These FR (superoxide anion) produce a lipid peroxidation on the cellular membranes $^{6,10,11}$. According to Graves et al. ${ }^{12}$, interference in the DNA replication occurs, due to Doxorubicin capacity to intercalate itself among the pairs of the basis ${ }^{12}$. There are, also, other reports on inhibition of DNA topoisomerase $\mathrm{II}^{13}$, mitochondrial damage, myocite disorder of the adrenergic function ${ }^{14,15}, \mathrm{Ca}^{++}$intracellular overcharge $^{16}$, and cytotoxic cytokine ${ }^{17}$. Apoptosis is very important not only in relation to cell loss during the physiological phenomenon, but also in relation to pathological processes, playing an important role in myocardiopathy pathogenicity ${ }^{18,19}$. Chen et al..$^{20}$ observed alterations in the cytosqueleton and myocite contractible elements which are, probably, related to myocardial dysfunction. Modification and inhibition of these mechanisms should be the objective of future studies.

This study observed that the presence of macro and microscopic myocardial alterations in rats treated with Doxorubicin are comparable to those observed in dilated myiocardiopathies. Therefore, we can deduce that this experimental model with be helpful in future studies on heart failure.

\section{Conclusion}

Doxorubicin was effective in promoting macro and microscopic alterations in the cardiac tissue of rats, and can, therefore, be used as a model for experimental studies in cardiomiopathy.

\section{References}

1. Henderson IC, Frei E 3rd. Adriamycin and the heart. N Engl J Med. 1979;300:310-2

2. Lefrak EA, Pitha J, Rosenheim S, Gottlieb JA. A clinicopathologic analysis of adriamycin cardiotoxicity. Cancer. 1973 32(2):302-14

3. Epstein RJ. Topoisomerases in human disease. Lancet. 1988;1(8584):521-4.

4. Von Hoff DD, Layard MW, Basa P, Davis HL Jr, Von Hoff AL, Rozencweig M, Muggia FM. Risk factrs for doxorubicin-induced congestive heart failure. Ann Intern Med. 1979;91(5):710-7.

5. Singal PK, Iliskovic N, Li T, Kumar D. Adriamycin cardiomyopathy: pathophysiology and prevention. FASEB J. 1997;11(12):931-6.

6. Iliskovic N, Singal PK. Lipid lowering: an important factor in preventing adriamycin-induced heart failure. Am J Pathol. 1997;150(2):727-34.

7. Mazue G, Iatropoulos M, Imondi A, Castellino S, Brughera M, Podesta A;,Torre PD, Moneta D. Anthracyclines: a review of general and special toxicity studies. Int J Oncol. 1995;7(4):713-24.

8. Podestà A, Della Torre P, Pinciroli G, Iatropoulos MJ, Brughera M, Mazué G. Evaluation of 4'-iodo-4'-deoxydoxorubicin-induced cardiotoxicity in two experimental rat models. Toxicol Pathol. 1994;22(1):68-71.

9. Majno G, Joris I. Apoptosis, oncosis and necrosis. An overview of cell death. Am J Pathol. 1995;146(1):3-15.

10. Olson RD, Mushlin PS. Doxorubicin cardiotoxicity: analysis of prevailing hypotheses. FASEB J. 1990;4(13):3076-86.

11. Abdel-aleem S, el-Merzabani MM, Sayed-Ahmed M, Taylor DA, Lowe JE. Acute and chronic effects of adriamycin on fatty acid oxidation in isolated cardiac myocytes. J Mol Cell Cardiol. 1997;29(2):789-97. 
12. Graves DE, Krugh TR. Adriamycin and daunorubicin bind in a cooperative manner to deoxyribonucleic acid. Biochemistry. 1983;22(16):3941-7.

13. Holm C, Stearns T, Botstein D. DNA topoisomerase II must act at mitosis to prevent nondisjunction and chromosome breakage. Mol Cell Biol. 1989;9(1):159-68.

14. Solem LE, Heller LJ, Wallace KB. Dose-dependent increase in sensitivity to calcium-induced mitochondrial dysfunction and cardiomyocyte cell injury by doxorubicin. J Moll Cell Cardiol. 1996;28(5):1023-32.

15. Valdés Olmos RA, ten Bokkel Huinink WW, ten Hoeve RF, van Tinteren $\mathrm{H}$, Bruning PF, van Vlies B, Hoefnagel CA. Assessment of anthracyclinerelated myocardial adrenergic derangement by (123I) metaiodobenzylguanidine scintigraphy. Eur J Cancer. 1995;31A(1):26-31.
16. Wang YX, Korth M. Effects of doxorubicin on excitationcontraction coupling in guinea pig ventricular myocardium. Circ Res. 1995;76(4):645-53.

17. Torre-Amione G, Kapadia S, Benedict C, Oral H, Young JB, Mann DL. Proinflammatory cytokine levels in patients with depressed left ventricular ejection fraction: a report from the studies of left ventricular dysfunction (SOLVD). J Am Coll Cardiol. 1996;27(5):1201-6.

18. Saraste A, Pulkki K, Kallajoki M, Henriksen K, Parvinen M, VoipioPulkki LM. Apoptosis in human acute myocardial infarction. Circulation. 1997;95(2):320-3.

19. Olivetti G, Abbi R, Quaini F, Kajstura J, Cheng W, Nitahara JA, Quaini E, Di Loreto C, Beltrami CA, Krajewski S, Reed JC, Anversa P. Apoptosis in the failing human heart. N Engl J Med. 1997;336(16):1131-41.

20. Chen J, Chien KR. Complexity in simplicity: monogenic disorders and complex cardiomyopathies. J Clin Invest. 1999;103(11):1483-5.

\section{Correspondence:}

José Carlos Dorsa Vieira Pontes

Av. Afonso Pena, 3088

79002-075 Campo Grande - MS Brazil

Phone: (55 67)3028-3380 / 8112-9986

carlosdorsa@uol.com.br

Conflict of interest: none

Financial source: none

Received: September 15, 2009

Review: November 17, 2009

Accepted: December 15, 2009

\section{How to cite this article}

Pontes JCDV, Gomes Júnior JF, Silva GVR, Benfatti RA, Dias AEMSAS, Duarte JJ, Gardenal N, Odashiro M, Santos CHM. Anatomopathological study of cardiomyopathy induced by doxorubicin in rats. Acta Cir Bras. [serial on the Internet] 2010 Mar-Apr;25(2). Available from URL: http://www.scielo.br/acb 